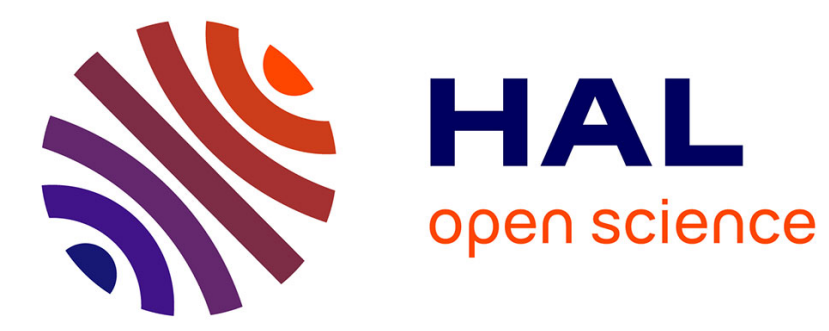

\title{
Environmental and strain effects on screening for Fire blight resistance
}

\author{
P. Lecomte, B. Thibault
}

\section{To cite this version:}

P. Lecomte, B. Thibault. Environmental and strain effects on screening for Fire blight resistance. Acta Horticulturae, 1990, 273, pp.343-350. hal-01600313

\section{HAL Id: hal-01600313 \\ https://hal.science/hal-01600313}

Submitted on 1 Jun 2020

HAL is a multi-disciplinary open access archive for the deposit and dissemination of scientific research documents, whether they are published or not. The documents may come from teaching and research institutions in France or abroad, or from public or private research centers.
L'archive ouverte pluridisciplinaire HAL, est destinée au dépôt et à la diffusion de documents scientifiques de niveau recherche, publiés ou non, émanant des établissements d'enseignement et de recherche français ou étrangers, des laboratoires publics ou privés.

\section{다(1)(2)}

Distributed under a Creative Commons Attribution - ShareAlike| 4.0 International 
R. L. Bell and T. van der Zwet

U. S. Department of Agriculture

Agricultural Research Service

Appalachian Fruit Research Station

Rearneysville, WW 25430, U.S.A.

B. Thibault

Station d'Amelioration Especes

Fruitiere et Ornamental
W. G. Bonn

Agriculture Canada

Research Station

Harrow, Ontario NOR 1GO

Canada

\section{P. Lecomte}

Station de Pathologie Vegetale et de Phytobacterologie Beaucouze, 49000 Angers, France

\section{Abstract}

Eleven genotypes of pear (Pyrus communis L.) and 5 strains of Erwinia amylovora Burr. (Winsl. et al.) were used in various combinations at three locations for two years in order to assess the degree of variability in disease expression due to random strain and environmental effects. For hosts and strains common to all locations and years, considerable variability among shoots in percent lesion length and in percentage of successful inoculation precluded detection of significant main effects in the full linear model, but sequential elimination of non-significant higher order interactions clarified interpretation of the data. Location, strain and year main effects, and all interactions were not significant. Although differences among host genotypes were significant, the choice of standard susceptible and resistant host plant genotypes in multi-location trials can be arbitrary. Strain E2002A, the Canadian standard bacterial strain, was highly aggressive, but not statistically superior. Increasing the number of replicated inoculations per experimental unit to at least 20, will increase the sensitivity of the future experiments, especially if substituted for yearly repetitions of identical experiments.

\section{Introduction}

Host plant resistance to fire blight, Erwinia amylovora Burrill (Winslow et al.), has been a major objective of pear breeding programs in the United States of America, Canada, and France, and will be important to programs in all countries into which the disease has spread. Cooperation and exchange of germplasm and data among programs will foster rapid progress. Determining relative resistance of cultivars, selections and other germplasm will be an important part of the selection and evaluation process. Varying environmental and biotic factors can have an effect on the degree of disease expression on given genotypes observed in various locations or years (van der Zwet and Keil, 1979). Because of this variability, standard cultivars could serve a useful purpose in the interpretation of shared data. Isolates used by each program may differ in aggressiveness, i.e., virulence, thereby influencing disease expression and detection of significant differences in host resistance. 
Several studies have addressed various interactions among strain and host, and among host and location or yearly variation. When susceptible cultivar, 'Bartlett' (synonym 'William's'), was inoculated with strains obtained from 9 pear cultivars, only minor variation in aggressiveness was observed. Although no significant host $x$ strain interaction was observed, Quamme and Bonn (1981) concluded that standardization of inoculum source was critical to obtain reproducible results in resistance studies in pears. When 7 scab-resistant apple cultivars were inoculated at 2 locations for three year with a mixture of 5 strains, no significant differences were observed in cultivar rank between locations, although year to year variability was evident at one location in overall severity (Bonn and Warner, 1987). Variability among yearly means, and to a lesser extent in host ranks, were also noted by Thibault et al., (1987). Norelli et al., (1984) have illustrated the existence and importance of specific host $x$ strain interactions in apple, while Paulin and Lespinasse (1987) did not detect interactions among some of the same strains and hosts.

This study was undertaken to provide an information base for cooperative evaluation programs. The major objective was to determine the degree of variability in disease expression due to the standard strains used by our programs, that due to the environmental factors associated with each location over a period of years, and that due to interactions among these factors. We also wished to derive from these data an optimum experimental design for further cooperative activities, and to determine whether a small standard set of hosts and strains could be chosen, based upon the relative ranks and stability.

\section{Materials and Methods}

Pear genotypes (Pyrus communis L.) and strains of Erwinia amylovora used are shown in Table 1. The standard US strain is Ea 273, E2002A is the Canadian standard, CNPB 2045 and CNBP 1430 are the old and new French standards, respectively, and E4001A is the 'Quinte' differential strain (Norelli et al.' 1984). Inoculations were carried out on orchard trees during $1987^{\prime}$ and 1988 at all three locations. The orchards were those of the authors respective research stations in the United States and Canada, and at the INRA research station at Dax in the province of Bordeaux, France. The set of host genotypes and strains used at each location differed somewhat, but a subset of four genotypes and two strains were common to all locations for both years.

\subsection{Inoculum}

The strains used in each location were obtained from the same sources to lessen the probability of genetic differentiation. Cultures of each strain were grown on NYDA and transferred daily onto slant cultures. Fresh inoculum was prepared daily by diluting the cultures into phosphate buffer and adjusting the concentration to approximately $5 \times 10^{8} \mathrm{cfu} / \mathrm{ml}$ using a calibrated turbidometer. 
is among strain ation. When a liam's'), was ¿s, only minor no significant a Bonn (1981) $s$ critical to jears. When 7 locations for nt differences hough year to rall severity ans, and to a bault et al., existence and apple, while ns among some

ion base for ive was to on due to the environmental of years, and so wished to for further standard set elative ranks

of Erwinia strain is Ea 1430 are the J01A is the Inoculations at all three respective at the INRA ce. The set on differed were common

ed from the erentiation. a daily onto liluting the ntration to ər.

\subsection{Shoot Inoculations}

Ten actively growing shoots selected from at least 2 trees of each host were inoculated at their tips with ca. $50 \mathrm{ul}$ of each culture suspension with a hypodermic syringe. After infection had ceased to progress, length of current season shoot, and length of necrosis were recorded. Frequency of infection and severity of infection as a percentage of current seasons growth ( 8 lesion length) were calculated.

\subsection{Statistical analyses_of sampling_variability}

The common set of 4 host genotypes and 2 strains were used to assess sampling varlability. All data, including that from to assess sampling
uninfected shoots, were transformed by $\log _{10}(8$ lesion length +1$)$
to improve normality and homogeneity of variances. The complete model was subjected to analysis of variance using a random effects model and partial sums of squares for all effects. Variance components were computed from partial sums of squares, using SAS PROC GLM Type III option (SAS Institute, Inc., 1987). A significance level of 0.50 was set for sequential removal of 3-way and then 2-way interaction terms from the linear model (Winer, 1971). Three cycles of analysis and removal of effects were performed. Components of variance and sample sizes necessary to detect differences among host genotypes were computed.

\section{Results and Discussion}

Analysis of $\log _{10}$ (\% lesion length) for the full model and common host and strain data (Cycle $I$, Table 2) resulted in no significant effects. This is a common problem in the analysis of random effect models of 3- and 4-factor experiments, due primarily to low degrees of freedom for the relevant error terms. Removal of the LHI interaction in Cycle II resulted in significant $(p=0.005)$ differences among hosts. In Cycle III, significance increased $(p=0.001)$.

of importance is that location and year main effects and interactions involving location and host were not significant. Of concern were the large error variance, which was probably due in some cases to the variable number of unsuccessful inoculations (Table 3 ), and the relatively large 4-way interaction. The sensitivity of joint experiments could be increased by several means:

1) Increasing the number of inoculated shoots. Computation of the LSDS for host differences, based upon the variances derived from the full model and $p=0.05$ for $10,20,30$, and 40 inoculated shoots are $70,49,40$, and $35 \%$, respectively.

2) Pooling data by eliminating main effects, such as year or strain, in addition to interactions, which do not meet the minimum probability criterion $(P=0.50)$, but only if they do not appear in any of the significant interactions that remain. 
3) Rank or other non-parametric statistics may offer another approach, especially if the objective is selection.

\subsection{Host Effects}

The five most resistant and the three most susceptible hosts in the Canadian tests were also among the most resistant or susceptible in the other trials, although the rank orders changed in infor factor was the generally low level of infection in 'Beurre Bosc' and 'Beurre d'Anjou' in the French for a standard upon these data, 'Williams' appears the logical choice

\subsection{Isolate Effects}

E2002A appeared to be the most aggressive strain, although considerable variability among shoots within the experimental units (host $\mathrm{x}$ location $\mathrm{x}$ year $\mathrm{x}$ strain combination) prevented statistical significance. Although strains did not differ significantly in Canada or the United States, differences were found among the strains used in France. In particular, CNBP 2045 was only weakly virulent at
this location.

\section{Conclusions}

Considerable variability in frequency of successful infection, and the resultant high error variance prevented the meaningful interpretation of standard errors, coefficients of variability, or other stability indices for individual hosts or strains, which would have aided in choosing stable standard hosts or strains. However the lack of significant interactions of these effects with environmental main effects indicates that hosts or strains do not vary considerably in stability of response. Therefore, the choice of standard resistant and/or susceptible hosts can be arbitrary. Standard strains should, of course, be chosen on basis of a high general aggressivenesis and frequency of successful infection. 
offer another ion.

$t$ susceptible resistant or irs changed in low level of 1 the French ogical choice

ain, although imental units a statistical ificantly in 9 . the strains $y$ virulent at

1 infection, $\geqslant$ meaningful iability, or which would s. However, ffects with ains do not 1e choice of arbitrary. ; of a high on.

\section{References}

Bonn, W. G., and Warner, J. 1987. Fire blight susceptibility of scab resistant apple cultivars. Can. J. Plant Pathol. 9:252-254 .

Norelli, J. L., Aldwinckle, H. S., and Beer, S. V. 1984. Differential host $x$ pathogen interactions among cultivars of apple and strains of Erwinia amylovora. Phytopathology 74:136-139.

paulin, J. P., and Lespinasse, J. 1987. Evaluation with different isolates of Erwinia amylovora of the susceptibility to fire blight of apple cultivars. Acta Horticulturae 217:253-261.

Quamme, H. A., and Bonn, W. G. 1981. Virulence of Erwinia amylovora and its influence on the determination of fire blight resistance of pear cultivars and seedlings. Can. J. Plant Pathol. 3:187-190.

SAS Institute Inc. 1987. SAS/STATTM guide for personal computers, version 6 edition. Cary, NC: SAS Institute Inc.

Thibault, B., Lecomte, P., Hermann, L., and Belouin, A. 1987. Assessment of the susceptibility to Erwinia amylovora of 90 varieties or selections of pear. Acta Horticulturae 217:305-309.

van der Zwet, T. 1977. Comparative sensitivity and response of various Pyrus tissues to infection by Erwinia amylovora. pp. 263-276. In: "Current Topics in Plant Pathology." Symp. Hung. Acad. Sci.,

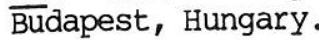

van der Zwet, T., and Keil, H. L. 1979. Fire blight: a bacterial disease of rosaceous plants. Agriculture Handbook No. 510, United States Department of Agriculture, Washington, D. C., 200 pp.

Winer, B. J. 1971. Statistical principles in experimental design. 2nd ed. Mograw-Hill, New York. pp.378-384. 
Table 1. Mean percentage lesion length, by host, strainz,
and location.

\begin{tabular}{lccc}
\hline \multirow{2}{*}{ Host } & \multicolumn{3}{c}{ Percent Lesion Length } \\
\cline { 2 - 4 } & Canada & France & United States \\
\hline Old Home & 9.1 & - & 0.2 \\
US 62537-048 & 10.4 & 1.1 & 10.7 \\
Magness & 11.8 & 0.7 & 6.5 \\
US 62563-004 & 12.1 & - & 1.0 \\
Moonglow & 16.3 & 0.1 & - \\
Harrow Delight & 16.5 & - & - \\
Clapp's Favorite & 33.9 & - & - \\
Williams & 46.5 & 48.9 & 64.4 \\
Beurre Bosc & 53.2 & 14.2 & - \\
Beurre.d'Anjou & 70.9 & 17.8 & 60.9 \\
\hline Pr > F & & & .01 \\
\hline \hline
\end{tabular}

\section{Isolate}

\begin{tabular}{lccc}
\hline E2002A & 36.7 & - & 34.3 \\
E4001A & 28.1 & 19.6 & 22.7 \\
CNBP 1430 & 19.1 & 17.6 & 23.2 \\
Ea 273 & - & 11.7 & 17.5 \\
CNBP 2045 & - & 6.2 & 22.0 \\
\hline Pr $>$ F & .08 & .01 & .07 \\
\hline
\end{tabular}

$\mathbf{Z}$ Includes only data available for both years. 
Table 2. Variance components of $\log _{10}$ percent lesion length. ${ }^{2}$

\begin{tabular}{|c|c|c|c|c|c|c|}
\hline \multirow[b]{2}{*}{ source } & \multicolumn{3}{|c|}{ Cycle I } & \multicolumn{3}{|c|}{ Cycle III } \\
\hline & d.f. & Var. & $\operatorname{Pr}>\mathrm{F}$ & d.f. & Var. & $\operatorname{Pr}>\mathrm{F}$ \\
\hline Location (L) & 2 & .010 & .35 & 2 & .014 & .15 \\
\hline Year $(Y)$ & 1 & .000 & .60 & 1 & .003 & .53 \\
\hline Host $(\mathrm{H})$ & 3 & .426 & .38 & 3 & .422 & .01 \\
\hline Strain (S) & 1 & .031 & .65 & 1 & .027 & .31 \\
\hline L X Y & 2 & .012 & .51 & -- & -- & -- \\
\hline $\mathrm{L} \times \mathrm{H}$ & 6 & .000 & .37 & 6 & .000 & .24 \\
\hline$L \times S$ & 2 & .000 & .54 & -- & -- & -- \\
\hline $\mathrm{Y} \times \mathrm{H}$ & 3 & .003 & .58 & -- & -- & - \\
\hline$Y \times S$ & 1 & .003 & .37 & 1 & .003 & .27 \\
\hline $\mathrm{H} \times \mathrm{S}$ & 3 & .000 & .90 & - & -- & -- \\
\hline $\mathrm{L} X \mathrm{Y} \times \mathrm{H}$ & 6 & .004 & .43 & 6 & .015 & .37 \\
\hline$L \times Y \times S$ & 2 & .002 & .24 & 2 & .009 & .18 \\
\hline $\mathrm{L} \times \mathrm{H} \times \mathrm{S}$ & 6 & .016 & .50 & -- & -- & -- \\
\hline $\mathrm{Y} \times \mathrm{H} \times \mathrm{S}$ & 3 & .011 & .24 & 3 & .001 & .41 \\
\hline $\mathrm{L} \times Y \times H \times S$ & 6 & .011 & .10 & 6 & .014 & .08 \\
\hline Residual Error & 400 & .359 & & 416 & .380 & \\
\hline
\end{tabular}

Z

Based upon all inoculated shoots. 
